J. Clin. Chem. Clin. Biochem.

Vol. 25, 1987, pp. $131-134$

(C) 1987 Walter de Gruyter \& Co.

Berlin - New York

\title{
Detection of a New Msp I Restriction Fragment Length Polymorphism in the Apolipoprotein A-I Gene
}

\author{
By H. Funke
}

Institut für Klinische Chemie und Laboratoriumsmedizin - Zentrallaboratorium - der Westfälischen WilhelmsUniversität

\section{J. Klug}

Institut für Klinische Chemie und Laboratoriumsmedizin - Zentrallaboratorium - der Westfälischen WilhelmsUniversität

Institut für Biochemie der Westfälischen Wilhelms-Universität Münster, F.R.G.

\section{P. Frossard}

California Biotechnology Inc., Palo Alto, CA 94303, U.S.A.

\section{J. Kowalski}

Institut für Klinische Chemie und Laboratoriumsmedizin - Zentrallaboratorium - der Westfälischen WilhelmsUniversität

\section{A. Reckwerth}

Institut für Arterioskleroseforschung an der Universität Münster, F.R.G. and

\section{G. Assmann}

Institut für Klinische Chemie und Laboratoriumsmedizin - Zentrallaboratorium - der Westfälischen WilhelmsUniversität

Institut für Arterioskleroseforschung an der Universität Münster, F.R.G.

(Received March 24/August 5, 1986)

Summary: We report the existence of a Msp I restriction fragment length polymorphism in the first intron of the apolipoprotein A-I gene that is different from the one described by Seilhamer et al. (DNA 3, 309 (1984)). Size comparison of the newly discovered Msp I fragment with a restriction map of the apolipoprotein A-I gene revealed that most likely the cutting site at the $5^{\prime}$-end of the normally seen $673 \mathrm{bp}$ fragment is lost giving rise to the observed $719 \mathrm{bp}$ Msp I fragment. Based on analyses of 136 DNAs of healthy and nonrelated caucasians the allelic frequency was determined to be 0.06 . The observed Msp I genotype frequencies are in Hardy-Weinberg equilibrium.

\section{Introduction}

In recent years epidemiologic studies have clearly demonstrated a reverse relationship between the plasma concentration of high density lipoproteins
(HDL) and the risk for the development of premature atherosclerosis (1). Coexistence of reduced HDL concentrations and frequent occurrence of myocardial infarctions has been observed in many families $(2,3)$. 
Thus, the risk for the development of atherosclerosis may in many cases be related to alterations in the genes controlling HDL metabolism.

Restriction fragment length polymorphisms have frequently been used in assessing the structural heterogeneity of genes (4). Furthermore they have been used in linkage studies $(4,5)$, as markers for the detection of disease $(6,7)$, as tracers for the identification of alleles in pedigree analyses (8), and in determining the clonal origin of tumours (9).

To date seven restriction fragment length polymorphisms $(10-12)$ have been identified within the genes for apolipoproteins A-I, C-III, and A-IV which are located next to each other within a $15 \mathrm{~kb}$ DNA fragment (13) in the region 11q13-qter on chromosome $11(14,15)$.

The identification of an additional polymorphism within the apolipoprotein A-I/C-III/A-IV gene cluster, which we report here, makes this gene locus more informative for genetic analyses.

\section{Materials and Methods}

\section{Leukocyte isolation}

Blood $(25 \mathrm{ml})$ was collected in a syringe prefilled with $1 \mathrm{ml}$ of $0.5 \mathrm{~mol} / 1 \mathrm{Na}_{2}$ EDTA pH 8.0 as an anticoagulant. Leukocytes were prepared by a modification of the method described by Gautreau et al. (16). Briefly, $25 \mathrm{ml} \mathrm{Na}_{2}$ EDTA-containing blood was centrifuged at $2000 \mathrm{~g}$ for $15 \mathrm{~min}$. The supernatant plasma was discarded and the tube was refilled to the original volume with $0.15 \mathrm{~mol} / 1 \mathrm{NaCl}$. This suspension was mixed with an equal volume of a solution containing $30 \mathrm{~g}$ dextran T 500 (Pharmacia, Freiburg, FRG) and $9 \mathrm{~g} \mathrm{NaCl}$ per liter, and taken up into a $50 \mathrm{ml}$ syringe, which was then allowed to stand on its plunger for $30 \mathrm{~min}$ to allow the erythrocytes to settle. The supernatant, containing the white cells, was centrifuged for $5 \mathrm{~min}$ at $2000 \mathrm{~g}$. Residual red cells contaminating the leukocyte pellet were lysed by the addition of water. After $30 \mathrm{~s}$ isotonicity was restored by the addition of $0.3 \mathrm{~mol} / 1 \mathrm{NaCl}$ and the leukocytes were pelleted at $2000 \mathrm{~g}$ for $5 \mathrm{~min}$.

\section{DNA isolation}

DNA was prepared from leukocytes by a method similar to the one reported by Geever et al. (7). Leukocytes were resuspended in $3 \mathrm{ml}$ of a buffer containing $20 \mathrm{mmol} / 1$ Tris- $\mathrm{Cl}(\mathrm{pH}$ 7.9), $1 \mathrm{mmol} / 1 \mathrm{Na}{ }_{2}$ EDTA, $0.3 \mathrm{~mol} / 1$ sodium acetate, $2 \mathrm{~g} / \mathrm{l} \mathrm{SDS}^{1}$ ) and proteinase $\mathrm{K}(170 \mathrm{mg} / \mathrm{l})$. Incubation was at $48^{\circ} \mathrm{C}$ for $12-$ $36 \mathrm{~h}$.

Proteins were removed by three extractions with phenol/chloroform/isoamylalcohol $(25+24+1)$ followed by three extractions with chloroform/isoamylalcohol $(24+1)$ alone. DNA was precipitated by the addition of 2.5 volumes of ice-cold ethanol. The DNA was pelleted at $2000 \mathrm{~g}$ for $5 \mathrm{~min}$. After

1) Abbreviations used: $\mathrm{Bp}=$ base pair, $\mathrm{cDNA}=$ complementary DNA, IVS = intervening sequence, $\mathrm{RNase} A=$ ribonuclease $\mathrm{A}, \mathrm{SDS}=$ sodium dodecylsulphate, $\mathrm{Msp} \mathrm{I}=\mathrm{a}$ restriction endonuclease from Moraxella species with the target sequence $\mathrm{C} \downarrow$ CGG. an additional wash with ethanol (volume fraction 0.7 ) the precipitate was dried in a Speed-Vac concentrator. The pellet .was resolubilized in $1.5 \mathrm{ml}$ Tris/EDTA buffer $(10 \mathrm{mmol} / 1$ Tris$\mathrm{Cl} \mathrm{pH} \mathrm{7.6,1} \mathrm{mmol/1} \mathrm{Na}_{2}$ EDTA). Five microlitres of an RNase A (Boehringer, Mannheim, FRG) solution (10 g/l RNase A, 10

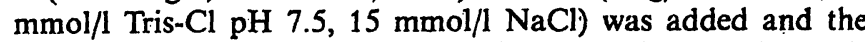
mixture was incubated at $37^{\circ} \mathrm{C}$ for $2-18 \mathrm{~h}$. Proteinase $\mathrm{K}$ (Boehringer, Mannheim, FRG) was added to give a final concentration of $170 \mathrm{mg} / \mathrm{l}$ and incubation was carried out overnight at $48^{\circ} \mathrm{C}$. Extraction, precipitation and drying were done as described above.

The pellet was resolubilized in sterile water and the concentration was determined by measuring the absorbance at $260 \mathrm{~nm}$. The total yield from $25 \mathrm{ml}$ blood was $400-800 \mu \mathrm{g}$ DNA. Virtually all DNA had a fragment length greater than $23 \mathrm{~kb}$.

\section{Southern blot}

Genomic DNA $(6 \mu \mathrm{g})$ was cut with the restriction endonuclease Msp I (Boehringer Mannheim, FRG) following the recommendations of the enzyme supplier. Electrophoresis was done in a $12 \mathrm{~g} / \mathrm{l}$ agarose gel (Agarose NA; Pharmacia, Freiburg, FRG) in tris/acetate buffer supplemented with $0.5 \mathrm{mg} / 1$ ethidium bromide. The DNA was transferred to nitrocellulose paper (BA 85; Schleicher \& Schüll, Dassel, FRG) by the procedure of Southern (17) using 12x SSC (1x SSC $=0.15 \mathrm{~mol} / \mathrm{l} \mathrm{NaCl}$, $15 \mathrm{mmol} / \mathrm{l}$ sodium citrate $\mathrm{pH} 7.0$ ). DNA was fixed on the nitrocellulose by baking at $80^{\circ} \mathrm{C}$ for $2 \mathrm{~h}$.

\section{Hybridization}

Conditions for hybridization with apolipoprotein A-I cDNA were exactly as described by Law et al. (18). The cDNA (600 bp Ava II fragment from pBL13AI, (10)) was radiolabelled by nick translation using the nick translation kit from NEN (Dreieich, FRG) following the supplier's instructions. The labelled nucleoside triphosphate was [ $\left.\alpha-{ }^{32} \mathrm{P}\right] \mathrm{dCTP}$ at a specific activity of $29.6 \mathrm{PBq} / \mathrm{mol}(800 \mathrm{Ci} / \mathrm{mmol})$. The nick translated $\mathrm{cDNA}$ was purified by chromatography on a $10 \mathrm{ml}$ Sephadex G-50 Fine column (Pharmacia, Freiburg, FRG) using Tris/EDTA buffer as mobile phase. Its specific activity was $0.4-1 \times 10^{8}$ counts $\min ^{-1} \cdot \mu \mathrm{g}^{-1}$ as calculated by Cerenkov counting and assuming a $100 \%$ recovery from the column.

The air-dried filters were wrapped in ultrathin plastic foil, placed on a Kodak XAR 5 film between two Kodak X=Omatic Regular intensifying screens, and stored at $-70^{\circ} \mathrm{C}$ for $1-4$ days.

\section{Results}

DNA was isolated from leukocytes of medical students of the University of Münster and assayed for the presence of the Msp I polymorphism described by Seilhamer et al. (10). In some DNAs the presence of a previously unidentified Msp I fragment was observed which migrated just above the regularly seen $673 \mathrm{bp}$ fragment (fig. 1). Comparison of the newly discovered fragment with a restriction map of the apolipoprotein A-I gene suggested that this fragment was generated by the loss of the cutting site at the $5^{\prime}$-end of the regular $673 \mathrm{bp}$ fragment. The alternative assumption that the loss of the cutting site occurs at the $3^{\prime}$-end of this fragment can be ruled out, because the expected $1.01 \mathrm{~kb}$ to $1.05 \mathrm{~kb}$ fragment is absent. 


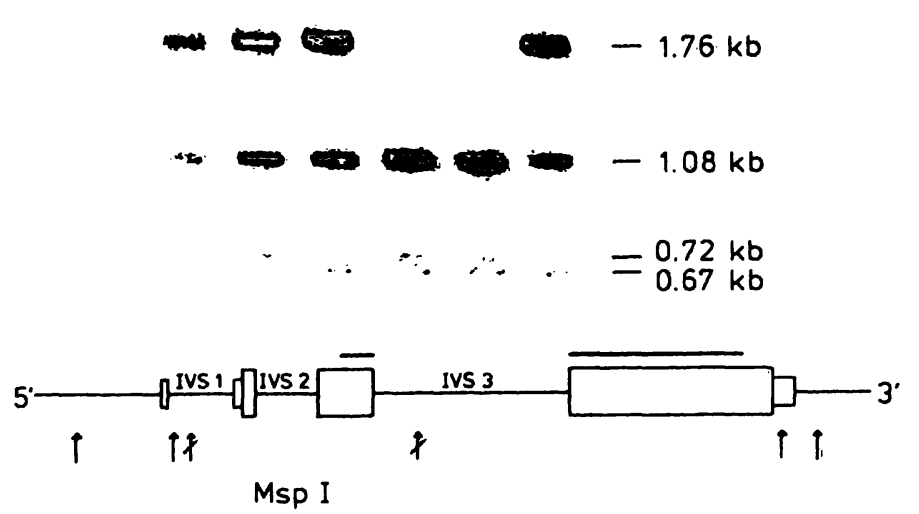

$0.1 \mathrm{~kb}$

Fig. 1. Msp I polymorphisms within the apolipoprotein A-I gene. The lower part shows a schematic drawing of the coding strand of the apolipoprotein A-I gene with boxes representing exon sequences. The bar on top of the boxes indicates the length of the cDNA used for hybridization. Normal Msp I cutting sites are indicated by arrows. The presence of all cutting sites leads to the detection of $0.67 \mathrm{~kb}$ and $1.08 \mathrm{~kb}$ Msp I fragments (allele A1). If the Msp I site within intron 3 (IVS 3 ) is absent, a $1.76 \mathrm{~kb}$ fragment is generated (allele A2). The absence of the Msp I site within intron 1 creates a $0.72 \mathrm{~kb}$ polymorphic fragment (allele A3). Individuals represented in lane 1,3, and 6 are heterozygous for the A2 allele (1.76 kb Msp I fragment), those represented in lanes 4 and 5 are heterozygous for the $A 3$ allele $(0.72 \mathrm{~kb}$ and $1.08 \mathrm{~kb}$ Msp I fragments). Lane 2 represents an individual heterozygous for both the $\mathrm{A} 2$ and $\mathrm{A} 3$ alleles.

The generation of the $0.72 \mathrm{~kb}$ polymorphic fragment by a small insertion was ruled out by the observation of regular size Stu I and Rsa I restriction fragments (data not shown).

Following a proposal of the Committee on Human Gene Mapping by Recombinant DNA Techniques (19) the observed Msp I alleles are designated A1, A2 and $\mathrm{A} 3$ according to decreasing allelic frequencies, with allele A1 being characterized by the regular 1.08 $\mathrm{kb}$ and $0.67 \mathrm{~kb}$ Msp I fragments (allelic frequency 0.81 ), allele $\mathrm{A} 2$ by an $1.76 \mathrm{~kb}$ Msp I fragment (allelic frequency 0.13 ), and allele $A 3$ by $0.72 \mathrm{~kb}$ and 1.08 $\mathrm{kb}$ Msp I fragments (allelic frequency 0.06).

Mendelian inheritance of the newly.discovered A3 allele was documented by the identification of an individual who is heterozygous for both the A2 and A3 alleles (fig. 1). Family analysis showed that this person had inherited allele A2 (1.76 kb Msp I fragment) from his mother and allele $\mathrm{A} 3(0.72 \mathrm{~kb}$ and $1.08 \mathrm{~kb} \mathrm{Msp} \mathrm{I} \mathrm{fragments)} \mathrm{from} \mathrm{his} \mathrm{father} \mathrm{(fig.} \mathrm{2).}$

The absence of both polymorphic Msp I cutting sites from the same DNA molecule would generate a 1.81 $\mathrm{kb}$ restriction fragment which may not be thoroughly

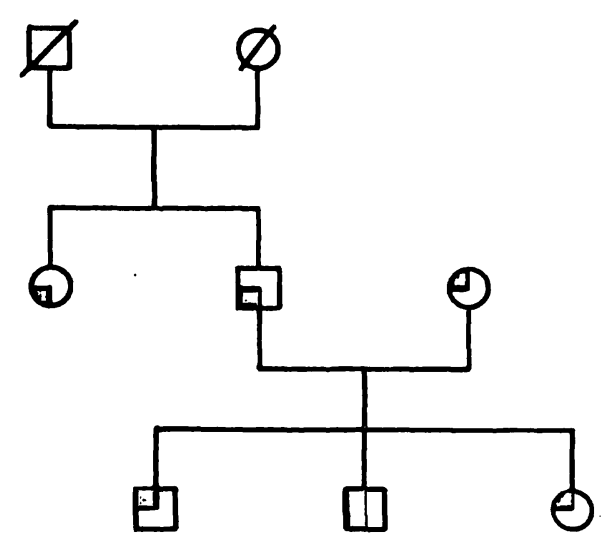

Fig. 2. Pedigree of a family with Msp I polymorphisms in the apolipoprotein A-I gene.

ש 0 Msp I (1.7) heterozygotes

(1) Msp I (0.72) heterozygotes

resolved from the $1.76 \mathrm{~kb}$ fragment with standard electrophoresis procedures. However, using Msp I/ Apa I and $\mathrm{Msp}$ I/Bcl I double digests, the existence of an allele characterized by the simultaneous absence of both Msp I sites could not be demonstrated.

From the analysis of DNA from 136 healthy and non-related caucasians the allelic frequency of the $\mathrm{A} 3$ allele was found to be 0.06 . In the same group the A2 allele had an allelic frequency of 0.13 , which is in agreement with the data reported by Coleman and coworkers (12).

Observed and expected $\mathrm{A} 1$ and $\mathrm{A} 3$ allele frequencies were compared by employing a $\chi^{2}$ test. They were found to be in Hardy-Weinberg equilibrium $\left(\chi^{2}=\right.$ $0.463, \mathrm{f}=1, \mathrm{p}>0.05$ ).

\section{Discussion}

The existence in the apolipoprotein A-I gene of a second Msp I polymorphism has been demonstrated. From restriction map analysis it appears likely that the new polymorphism is based on the loss of a regular Msp I cutting site. A base exchange as well as the methylation of a cytosine within the recognition sequence could provide the structural basis for the generation of the $0.72 \mathrm{~kb}$ fragment of the A3 allele. Msp I is sensitive to a ${ }^{\mathrm{me} C C G G}$ methylation, but not to the more frequently observed $\mathrm{C}^{\mathrm{me}} \mathrm{CGG}$ methylation (20). As CpG dinucleotide sequences have been demonstrated to be hot spots for $\mathrm{C}$ to $\mathrm{T}$ transitions (21), it can be hypothesized that this base exchange may be the underlying structural basis for the newly observed polymorphism. A definite decision, however, can only be made after sequence analysis. 
The new Msp I polymorphism described here helps to increase the degree of polymorphism in the apolipoprotein A-I/C-III/A-IV gene cluster and thus makes this locus a better marker and a better tool for analysing disorders of high density lipoprotein metabolism.

The information content of all restriction fragment length polymorphisms in the apolipoprotein A-I/C-

\section{References}

1. Assmann, G. (1982) Lipid metabolism and atherosclerosis. Schattauer Verlag, Stuttgart.

2. Vergani, C. \& Bettale, A. (1981) Clin. Chim. Acta 114, 45-52.

3. Micheli, H., Pometta, O., Jarnot, C. \& Scherrer, J. R. (1979) Atherosclerosis 32, 269-276.

4. Botstein, D., White, R. L., Skolnick, M. H. \& Davis, R. W. (1980) Am. J. Hum. Genet. 32, 314-331.

5. White, R., Leppert, M., Bishop, D. T., Barker, D., Berkowitz, J., Brown, C., Callahan, P., Holm, T. \& Jerominski, L. (1985) Nature 313, 101-105.

6. Gusella, J. F., Wexler, N. S. \& Connealy, P. M. (1983) Nature 306. 234-238.

7. Geever, R. G., Wilson, C. B., Nallaseth, F. S., Milner, P. F., Bittner, M. \& Wilson, J. T. (1981) Proc. Natl. Acad. Sci. USA 78, $5081-5084$.

8. Kazazian, H. H. Jr., Antonarakis, S., E., Cheng, T., Boehm, C. D. \& Waber, P. G. (1983) DNA polymorphisms in the $\beta$-globin gene cluster: use in discovery of mutations and prenatal diagnosis. In: Banbury Report 14 (Caskey, C. T. \& White, R. L., eds.) Cold Spring Harbor.

9. Vogelstein, B., Fearon, E. R., Hamilton, S. R. \& Feinberg, A. P. (1985) Science 227, 642-645.

10. Seilhamer, J. J., Protter, A. A., Frossard, P. M. \& LevyWilson, B. (1984) DNA 3, 309-317.
III/A-IV gene cluster is sufficient to use this gene complex as a DNA marker locus for genetic linkage studies as proposed by Botstein et al. (4).

\section{Acknowledgement}

We wish to thank $T$. Terrahe for expert ássistance in photography. This research was supported by a grant from the Deutsche Forschungsgemeinschaft.

11. Kessling, A. M., Horsthemke, B. \& Humphries, S. E. (1985) Clin. Genet. 28, 296-306.

12. Coleman, R. T., Gonzales, P. A., Funke, H., Assmann, G., Levy-Wilson, B. \& Frossara, P. M. (1986) Mol. Biol. Med. 3. $213=228$.

13. Karathanasiș, S. K. (1985) Proc. Naț. Acad. Sci. USA 82 , 6374-6378.

14. Law, S. W. \& Brewer, H. B. Jr. (1984) Proc. Natl. Acad. Sci. USA 81, 66-70.

15. Cheung, P., Kao, F. T., Law, M. L., Jones, C., Puck, T. T. \& Chan, L. (1984) Proc. Natl. Acad. Sci. USA 81, 508511.

16. Gautreau, C., Rahuél, C., Cartron, J. P. \& Lucotte, G. (1983) Anal. Biochem. 134, 320-324.

17. Southern, E. M. (1975) J. Mol. Biol. 98, 503-517.

18. Law, D. J., Frossard, P. M. \& Rucknagel, D. L. (1984) Gène 28, 153-158.

19. Skolnick, M. H., Willard, H. F. \& Menlove, L. A. (1984) Cytogenet. Cell Genet. 37, 210-248.

20. Kessler, C., Neumeier, T. S. \& Wolff, W: (1985) Gene 33, 1-102.

21. Barker, D., Schafer, M. \& White, R. (1984) Cell 36, 131 138.

Harald Funke

Institut für Klinische Chemie

und Laboratoriumsmedizin

Albert-Schweitzer-Str. 33

D-4400 Münster 